\title{
Discussie over robotisering en arbeidsmarkt behoeft onderzoeksdata
}

\author{
Peter Smulders*
}

Weinig publicaties hebben de laatste jaren zoveel losgemaakt als die van de Britse onderzoekers Frey en Osborne (2013) en de Amerikanen Brynjolfsson en McAfee (2014) over de technologische ontwikkelingen en de arbeidsmarkteffecten. Frey en Osborne (2013) kwamen tot de conclusie dat 47\% van de Amerikaanse beroepen - namelijk die waarbij veel herhalende bewegingen met de hand en de vingers gemaakt dienen te worden - de komende twintig jaar een hoog risico loopt op robotisering of computerisering. Moeilijk te computeriseren zou het werk zijn van hoogopgeleide beroepen, waarin creativiteit, originaliteit, onderhandelen, overtuigen en/of zorgen nodig is.

In de Nederlandse pers volgden vele artikelen en columns over dit thema. Ook dit tijdschrift wijdde er het tweede nummer van 2015 gedeeltelijk aan. Minister Asscher van SZW liet er zich in september 2014 over uit. De bewindsman concludeerde substantiële robotisering niet voor onmogelijk te houden. Er kwam een kabinetsbrief aan de Tweede Kamer (Ministerie van SZW, 2014), waarin meer accent bepleit werd op ICT-gerelateerde opleidingen, dit in verband met te verwachten veranderingen in de vraag naar arbeid. Hiermee volgde de Nederlandse overheid de OECD (Organisation for Economic Co-operation and Development), die de 'digitale economie' als een topprioriteit aangemerkt had en - met het oog op de toekomstige werkgelegenheid - de 34 aangesloten landen opriep de hoogste prioriteit te geven aan de ontwikkeling van ICT-kennis en -vaardigheden (OECD, 2014).

De centrale vraag is natuurlijk wat de effecten van technologisering (een begrip dat automatisering, digitalisering, computerisering en robotisering omvat) zouden kunnen zijn op de werkgelegenheid. Daaraan wijdde de Commissie SZW van de Tweede Kamer op 7 september 2015 een hoorzitting. De arbeidsmarktdeskundigen die op die dag ondervraagd werden, waren over het algemeen optimistisch (in het verleden bleek het effect van technologisering op de arbeidsmarkt per saldo altijd mee te vallen) tot vraagtekens plaatsend (eigenlijk weten we niet hoe technologie en arbeidsmarkt zich zullen ontwikkelen).

Daarnaast verscheen er een aantal veelbesproken rapporten over de materie. Het Rathenau Instituut (Van Est \& Kool, 2015) hield het erop dat zowel baanverlies als baancreatie mogelijk zou zijn. De notitie van het CPB over de technologische ontwikkelingen (Van den Berge \& Ter Weel, 2015) was daarentegen

* Peter Smulders is research fellow bij TNO Work \& Employment en redacteur van TvA. E-mail: peter.smulders@tno.nl 
uitgesproken positief: technologische verandering zou tot hogere productiviteit, meer werkgelegenheid en meer welvaart leiden.

Het recente WRR-rapport over robotisering (Went et al., 2015) concludeerde eveneens dat het helemaal niet zo'n vaart zal lopen met de robotisering. Bij bedrijven die robots zouden kunnen gebruiken, worden installatieproblemen gesignaleerd. Ook zouden bedrijven ze nog te duur vinden en zouden klanten er niet op zitten te wachten, bijvoorbeeld die in de zorgcentra. Over de arbeidsmarkteffecten van de robotisering gaat een hoofdstuk van Van den Berge en Ter Weel van het CPB. Zij stellen dat er historisch gezien geen reden voor angst is. Er zijn namelijk verscheidene technologische revoluties geweest en per saldo kwamen er steeds meer banen bij dan er verdwenen. Maar ook concluderen de CPB-auteurs dat er nauwelijks empirische studies zijn over waar we nu precies staan in de IT-ontwikkelingen en wat de gevolgen zijn voor de arbeidsmarkt. Dit lijken toch wat moeilijk te rijmen uitspraken.

Alles bij elkaar kan geconcludeerd worden dat er - ondanks de publicaties van het Rathenau Instituut, het CPB en de WRR - stevige lacunes voorkomen in de kennis over technologisering en over de relatie met de arbeidsmarkt. Zo is er bijvoorbeeld weinig informatie over de ontwikkelingen in de tijd bij bedrijfssectoren en beroepsgroepen. Waar zijn die robots en andere IT-toepassingen bijvoorbeeld ingevoerd? In welke aantallen? En zijn die bedrijfssectoren en beroepsgroepen inderdaad in omvang afgenomen of toegenomen? En welke invloed hebben de technologische ontwikkelingen gehad op de inhoud van werk/taken en van afdelingen? Is er sprake van substitutie (verlies van taken aan de technologie) of van complementariteit (het ontstaan van nieuwe taken of een hogere kwaliteit van werk door de technologie)? En hoe staat het met de 'organizational choice': hebben managers in overeenkomstige automatiseringssituaties inderdaad verschillende oplossingen gekozen?

Hier ligt een serieuze taak voor het CBS en de planbureaus die zich bezighouden met het monitoren van de ontwikkelingen rond arbeid en arbeidsmarkt in Nederland. Maar ook lijkt het een goed idee dat de ministeries van SZW en EZ een onderzoeksplan inclusief financiële middelen op dit gebied ontwikkelen, waarop onderzoeksinstanties kunnen intekenen. Ten slotte ligt het voor de hand dat de Sociaal-Economische Raad nader onderzoek opneemt in het advies dat door de minister van SZW (Ministerie van SZW, 2015) gevraagd is over deze materie.

Bij dit alles dient rekening te worden gehouden met het punt dat de vervanging van werk door de technologisering lang niet de enige 'driver' is van arbeidsmarktgroei en -krimp. De arbeidsmarktprognoses van het Amerikaanse Department of Labor (Hogan \& Roberts, 2015) gaan er bijvoorbeeld van uit dat demografische ontwikkelingen een rol spelen in groei en krimp van werk. Zo vormt de verouderende en zorgbehoevende bevolking een belangrijke groeistimulans voor de zorgsector. Andere 'drivers' van arbeidsmarktgroei en -krimp zijn veranderende voorkeuren van consumenten, andere wijzen van organiseren of produceren en verplaatsing van productie naar het buitenland (outsourcing). Over de periode 2014-2024 verwacht het ministerie dat de grootste banengroei in de VS gerealiseerd wordt in de gezondheidszorg (verpleegkundigen, fysiotherapeuten, thuiszorgpersoneel). De grootste banenkrimp verwacht men in de productiesectoren en de landbouw, bosbouw en visserij. 
Een beperkt deel van de benodigde kennis is overigens elders reeds beschikbaar. De European Working Conditions Survey 2010 laat bijvoorbeeld zien dat automatiseringsprocessen in Europa vooral plaatsvinden bij banken en andere financiële instellingen, in de telecommunicatie, bij energie- en waterbedrijven, in ziekenhuizen en bij de overheid. Verder hebben leidinggevenden, technici en vakspecialisten het meest met automatisering te maken en lager opgeleiden het minst (Smulders, 2014, 2015). Deze sectoren en beroepen overziend mag wel duidelijk zijn dat er veel meer plaatsvindt op het gebied van de digitalisering in brede zin dan op het gebied van de robotisering.

\section{Literatuur}

Berge, W. van den \& Ter Weel, B. (2015). Nieuwe kansen door technologie. Baanpolarisatie in Nederland. Den Haag: Centraal Planbureau.

Brynjolfsson, E. \& McAfee, A. (2014). The second machine age: Work, progress, and prosperity in a time of brilliant technologies. New York/London: Horton.

Est, R. van \& Kool, L. (2015). Werken aan de robotsamenleving. Visies en inzichten uit de wetenschap over de relatie technologie en werkgelegenheid. Den Haag: Rathenau Instituut.

Frey, C. \& Osborne, M. (2013). The future of employment: How susceptible are jobs to computerization? Oxford: University of Oxford.

OECD (2014). Skills and jobs in the Internet economy. OECD Digital Economy Papers, No. 242, Paris: OECD Publishing.

Hogan, A. \& Roberts, B. (2015). Occupational employment projections to 2024. Monthly Labor Review, August.

Ministerie van Sociale Zaken en Werkgelegenheid (2014). Effect van technologische ontwikkelingen op de arbeidsmarkt. Brief aan de Tweede Kamer, 19 december 2014. Den Haag: Ministerie van SZW.

Ministerie van Sociale Zaken en Werkgelegenheid (2015). SER-adviesaanvraag Effecten van technologische ontwikkelingen op de arbeidsmarkt en arbeidsverhoudingen. Den Haag: Ministerie van SZW, Brief aan de Sociaal-Economische Raad, 30 november 2015.

Smulders, P.G.W. (2014). Automatisering in Nederland en Europa. Economisch Statistische Berichten, 99(4696), 651-652.

Smulders, P.G.W. (2015). Technologische innovatie naar beroep en werkplek. Economisch Statistische Berichten, 100(4708), 237-239.

Went, R., Kremer, M. \& Knottnerus, A. (red.) (2015). De robot de baas. De toekomst van werk in het tweede machinetijdsperk. Amsterdam: Amsterdam University Press. 